\title{
PSYCHE.
}

\section{A NEW BLEPHAROCERID.}

BY VERNON L. KEILOGG, STANFORD UNIVERSITY, CALIF.

The family of Blepharoceridae, as at present known, includes about fifteen species of nematocerous Diptera, of unusual interest to entomologists. This interest is caused by the rarity of specimens in collections, by the unique structural condition of the larva, by the strange, although as yet imperfectly known, life history and habits, and finally by the peculiar accessory venation and suggestive structural character of the moutlıparts and *compound eyes of the imagines.

In the summer of $1895, \mathrm{Mr}$. R. W. Doane, at that time collecting for me in the vicinity of this University (Stanford), took two females and a male of a Blepharocerid species. I have only recently given these specimens any attention other than the rather unkind one of removing the heads of two (the male and one female) in order to study their mouthparts. A recent examination of the specimens reveals the fact that they are representatives of an undescribed species which may be assigned to Löw's genus Liponeura (Stett. Ent. Zeit. I844, vcl. v, p. I I8).

* See Kellogg, Notes on the Life-history and Structure of Blepharocera capitata Löw; Ent. News, 19oo, vol. X, pp. 305-318.
The new species may be described as follows :

Liponeura doanei n. sp. Female; length $6 \mathrm{~mm}$., length of wing $7 \frac{1}{2} \mathrm{~mm}$.; very pale brown, almost clayey; antennae $\mathrm{I}_{4}$-segmented and rising from a prominence which

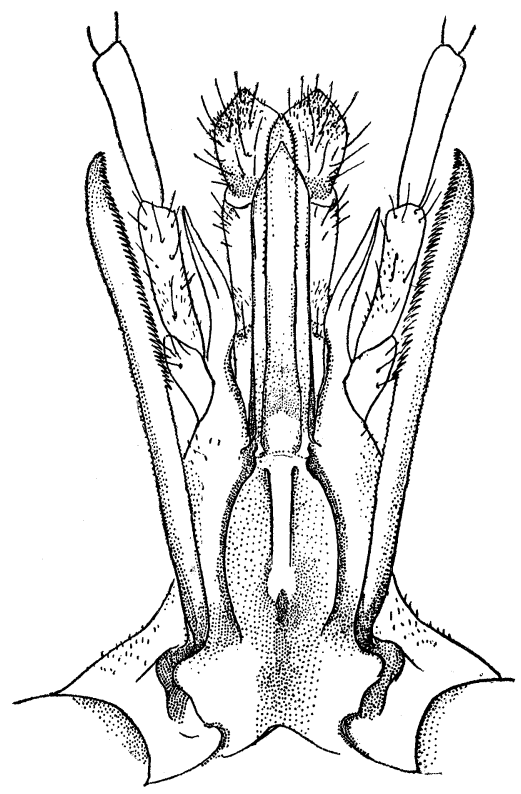

Fig. I. Mouthparts of Liponeura doanei n. sp.

might be construed to be a basal antennal segment; eyes broadly separated, and with no indications of bisection, the facets being 
all of the same size; the mouthparts (fig. I) long (distinctly longer than in Blepharocera, for example) and composed of long slender. flattened well chitinized mandibles with the apical two-fifths of the inner margin finely serrate, and inserted farther back on the head than the other mouthparts; of maxillae consisting of slender flattened tapering bladelike terminal lobes and long five-segmented palpi; of elongate simple labium consisting of basal portion and one pair of free terminal lobes; and of slender elongate flattened labrum epipharynx and hypopharynx; wings with venation (fig. 2) showing the following characters (given first in the nomenclature used by Comstock and in following parentheses in the nomenclature used by Osten Sacken in the latest revisional paper

basal rudiment present (auxiliary vein wanting or with only a basal rudiment present). Wings clear, with strong iride scent reflections. The legs are long, the three pairs of about equal length, the hind tibiae bearing a single terminal spur, the other tibiae without spurs. The tarsal claws are large, thick and strong with curved pointed tip, thickly pectinate except at the tip. The external genitalia consist of a pair of flattened triangular dorsal plates.

Male. The male is slightly smaller than the female. As the head of the only male specimen was destroyed in the dissection of the mouthparts before any examination of the specimen was made, it cannot be said whether the eyes are like those of the female or not; mouthparts like those of the females except that the mandibles are wholly lacking. Wings and legs like female. The conspicuous parts of the external genitalia are a pair of large articulated claspers, a broad ventral plate, and a smaller dorsal plate.

Described from two

Fig. 2. Venation of Liponeura doanein.sp.

of the Blepharoceridae); vein $\mathrm{M}_{3}$ independent, i. e. without connection with $M$ or any other principal vein (an incomplete vein running into the posterior margin between veins 4 and 5 ); veins $R_{2}$ and $R_{3}$ coalesced to the margin (vein 2 simple, unbranched); a medio-cubital cross vein (a cross-vein between veins 4 and 5 ); veins $R_{2}+_{3}$ and $R_{4}+_{5}$ separating at the origin of the radiomedial cross vein (the sub-marginal cell sessile); the radial sector springing from $R$ by two roots (the cross vein between veins $I$ and $2 \mathbf{Y}$-shaped, that is the anterior half of it divided, enclosing a small triangular cell); sub-costa wanting or with only a

* Osten Sacken C. R. Contributions to the study of the Liponeuridae Loew (Blepharoceridae Loew, olim) Berl. Ent. Zeitsch. 1895, Bd. xl, pp. 148-169. females and one male, taken by R. W. Doane, July 24, I895, on the banks of a small stream in the Santa Cruz Mts. at Congress Springs, Santa Clara County, California.

The new species can readily be grouped with the four other known species assigned to the genus Liponeura in Osten Sacken's* paper. The new form has in common with the other four species an incomplete vein running into the posterior margin of the wing between veins 4 and 5 , a simple (un-

* Osten Sacken C. R. loc. cit 
branched) second longitudinal vein, and eyes separated by a broad front. Within the genus, the new form agrees with bilobata Löw and yosemite O.S. in possessing a cross vein between veins 4 and 5, and finally resembles bilobata in having the sub-marginal cell sessile. But it differs from bilobata (as from all other Blepharoceridae) in having the radial sector springing from two roots (the base of the second longitudinal vein forked) so that a small triangular cell is formed behind $R_{1}$ (first longitudinal vein).

The only other Blepharoceridae so far known from the Pacific Coast are Blepharocera ancilla O. S. (California) and Liponeura yosemite O.S. (Yosemite Canon, California), from both of which the new species differs sharply in the character of the eyes and venation.

Unfortunately I have not been able yet to find the immature stages of the new species, so can add nothing to our incomplete knowledge of the interesting life-history of the members of the family.

One of the moot points regarding the biology of the Blepharoceridae is

\section{PROCEEDINGS OF THE CLUB.}

12 JANUARY, 1900. The $2 \mathrm{I}$ th regular and $23 \mathrm{~d}$ annual meeting (since incorporation) was held at ${ }_{5} 6$ Brattle St., Mr. W. L. W. Field in the chair.

Reports from the several officers were received and the following officers elected for the ensuing year:- President, J. W. Folsom; secretary, Roland Hayward ; treasurer, Samuel Henshaw; librarian, Samuel H. Scudder; members at large of the executive committee, A. S. Hewins and A. P. Morse. that of the dimorphism of the female. I have elsewhere ${ }^{*}$ referred to Fritz Müller's statement that there are two kinds of females of Paltostoma torrentium (Brazil), one kind possessing mandibles and being blood-sucking, the other kind having no mandibles and being nectar-sucking. Osten Sacken deems the evidence of dimorphism insufficient. Of twenty-three females of Blepharocera capitata Löw taken by me at Ithaca, N. Y., no one was without mandibles, nor was there any other difference apparent. Most of these specimens were taken just as they were issuing from the pupal skins on various days, in various parts of the stream, so the criticism that one kind of female might possess habits rendering it more likely to be caught than the other, will not hold in this instance. It seems to me probable that there is no dimorphism of the females of Blepharocera capitata Löw. In the case of the new Californian species I can only say that both females (the only ones so far taken) agree in possessing mandibles, and in all other characters.

The address of the retiring president, A. G. Mayer, on the mating instinct in moths was next read. (See Psyche for February.) Much discussion followed, in which all present participated.

Mr. W. L. W. Field spoke of a cocoon of Samia cynthia which he had seen containing two pupae. In outward appearance, however, it showed no apparent difference from a normal cocoon of that species. 

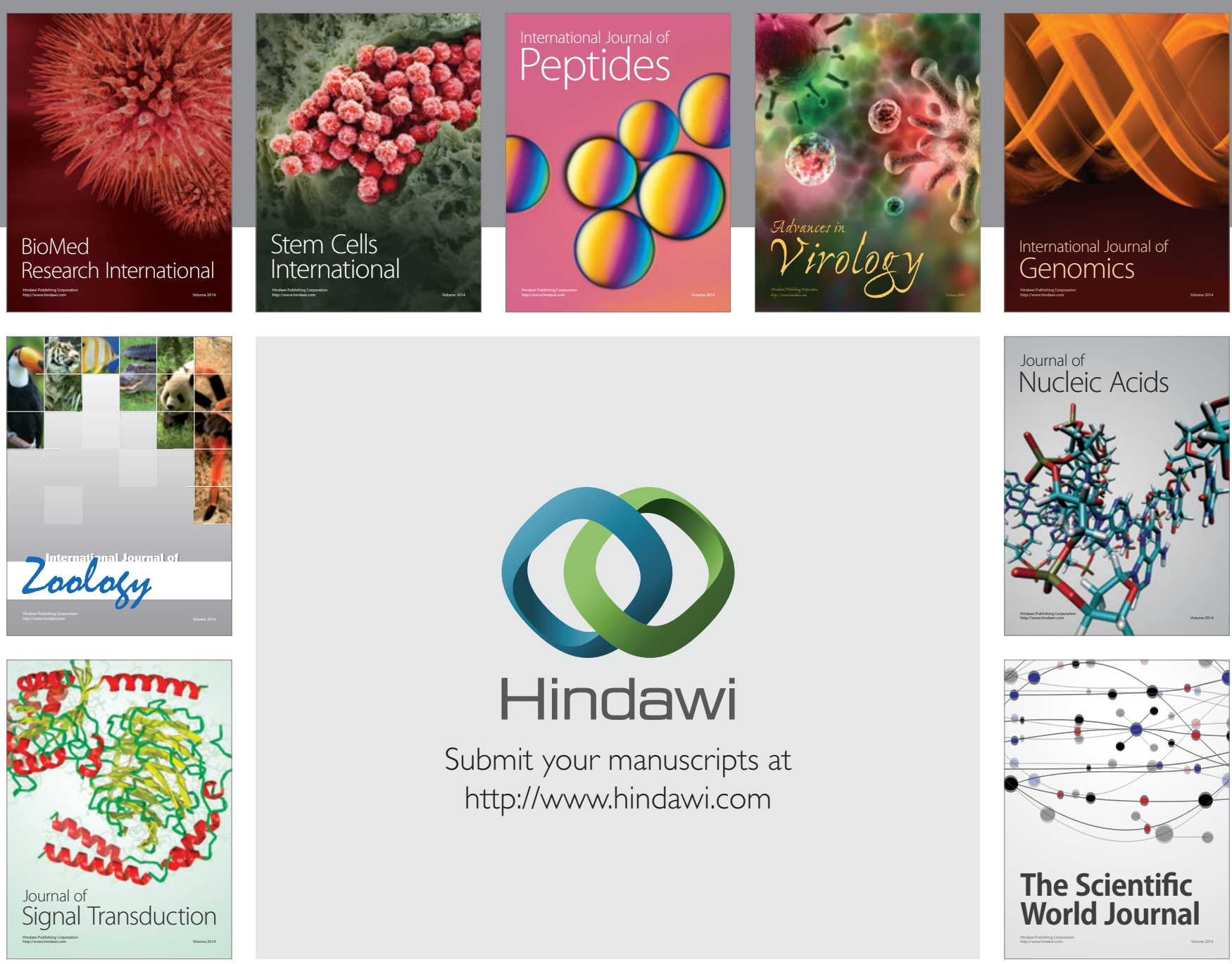

Submit your manuscripts at

http://www.hindawi.com
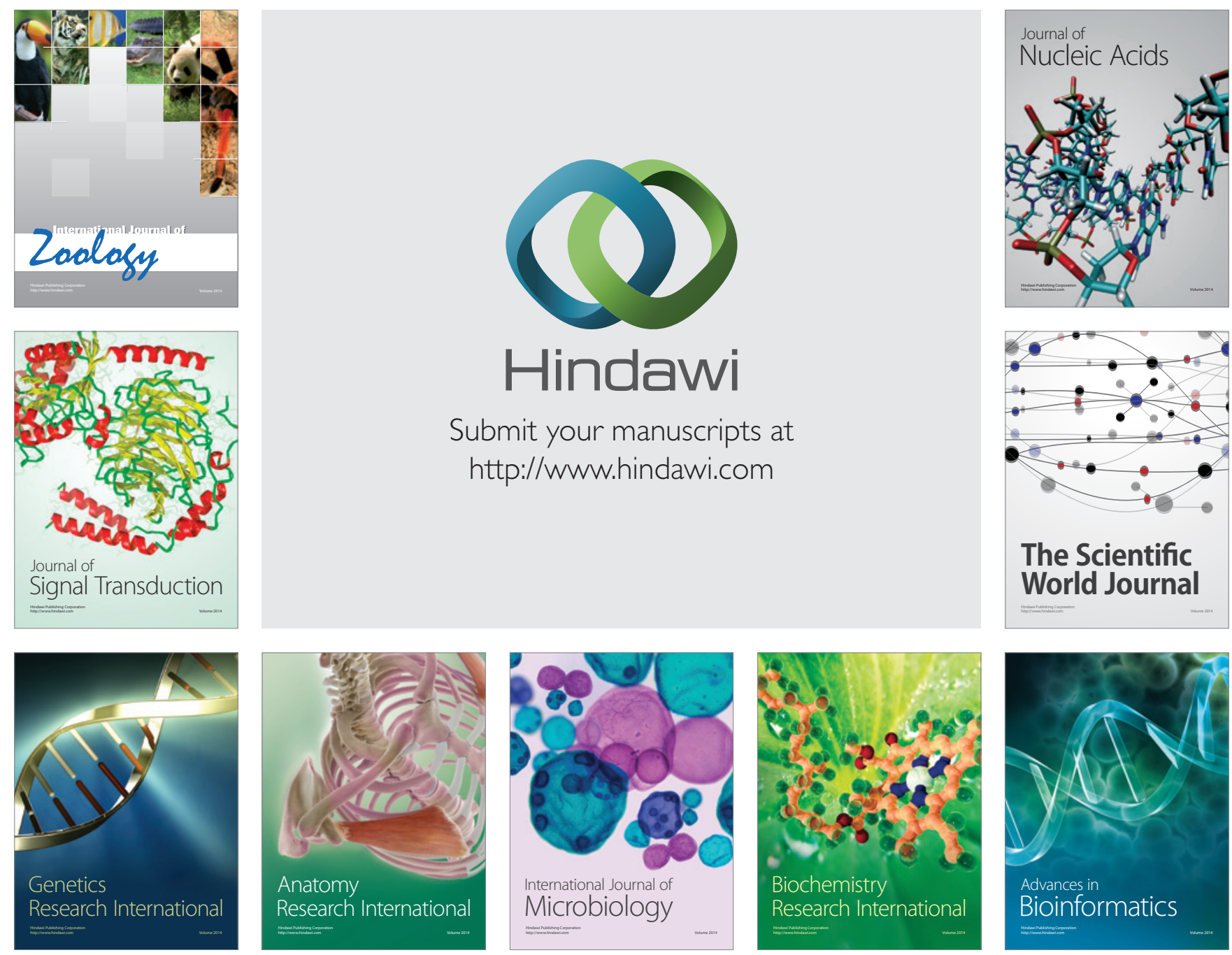

The Scientific World Journal
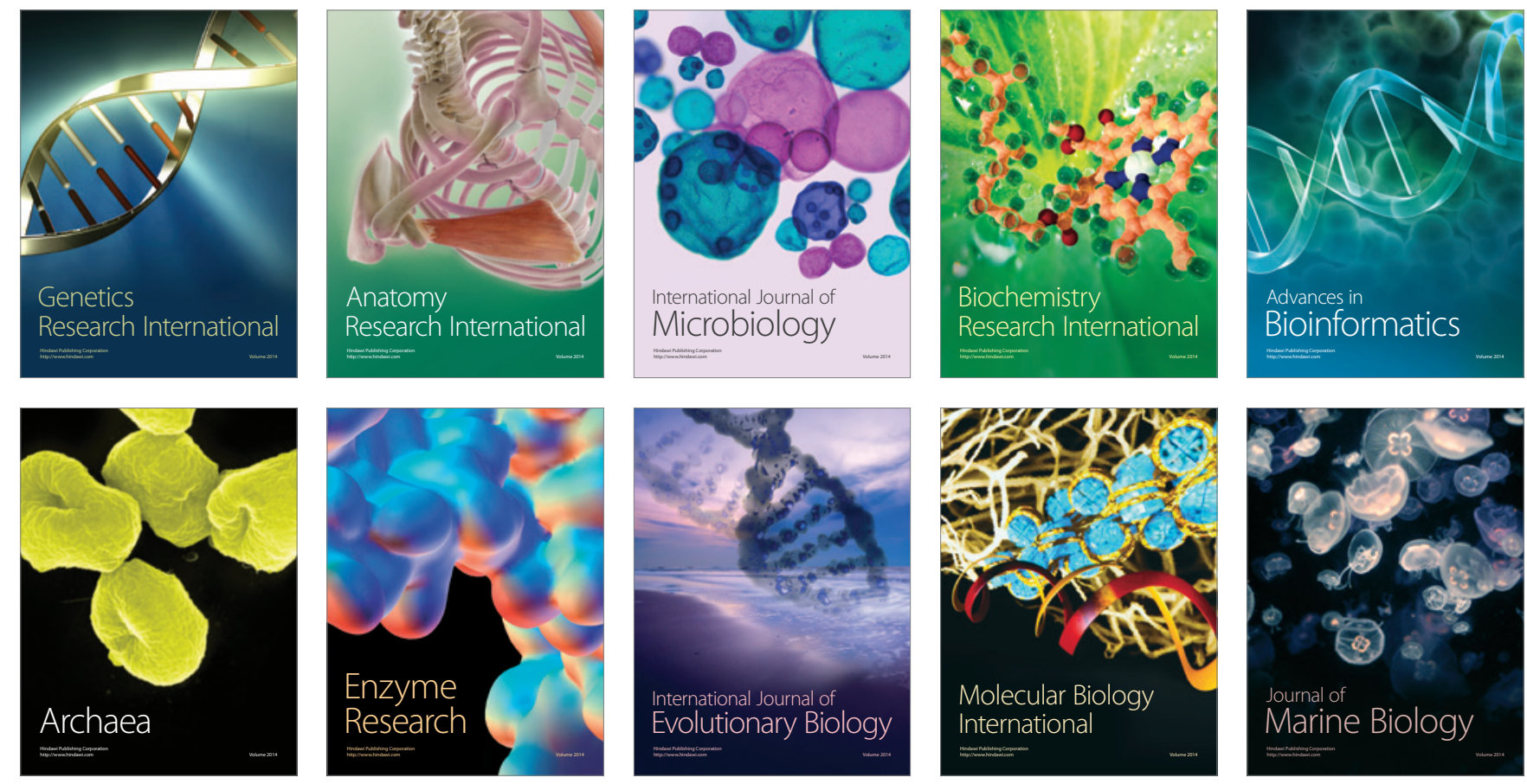